\title{
Cognitive Characteristics of Gifted and Not Gifted Fifth-grade Chilean Students from Economically Vulnerable Contexts
}

\author{
Violeta Arancibia ${ }^{1, *}$, Diana Boyanova ${ }^{2}$, Pablo González ${ }^{2}$ \\ ${ }^{1}$ Department of Psychology, Pontifical Catholic University of Chile, Chile \\ ${ }^{2}$ PENTA UC, Pontifical Catholic University of Chile, Chile
}

Copyright $(2016$ by authors, all rights reserved. Authors agree that this article remains permanently open access under the terms of the Creative Commons Attribution License 4.0 International License

\begin{abstract}
The purpose of the study was to reveal the cognitive characteristics of talented children who come from economically vulnerable contexts in Chile. Raven's Standard Progressive Matrices (SPM) was administered to a sample of 5160 students who took part in the process of identification of gifted students from the program PENTA UC in Chile between 2001 and 2010, when the participants were in the fifth grade. Results showed that there is a possible ceiling effect in SPM and thus Advanced Progressive Matrices might be more appropriate in the future identification process. Gifted Chilean students from public schools differ from not gifted students in both perceptual and analytical abilities, even at the early age of 10-11 years. Important gender differences emerged in solving the most difficult items of the test, more precisely in the rules applied in their solution. Gifted boys showed an advantage in addition/subtraction or distribution of two rules, whereas gifted girls did better in distribution of three rules. Results from this study could contribute not only to the process of identification of gifted students, but also to the proposition of adequate educational policy, corresponding to the cognitive characteristics of the children with academic talent.
\end{abstract}

Keywords Academic Talent, Low Socioeconomic Status, Analytical Abilities, Raven's Matrices, Sex Differences

\section{Cognitive Characteristics of Gifted and Not Gifted Fifth-grade Chilean Students from Economically Vulnerable Contexts}

\section{Cognitive Characteristics of Adolescents with Academic} Talent

The cognitive characteristics of talented children are mostly identified in comparison to the cognitive characteristic of not talented ones. Steiner and Carr [1] summarized a series of studies reporting the differences between talented and not talented children in four main aspects: process speed, knowledge base, metacognitive skills and problem solving and strategic abilities. An earlier study supported the idea that gifted students do not use qualitatively different thinking abilities, but rather use the same ones "better, faster and at earlier age" (Rogers, 1986 as cited in Robinson \& Clinkenbeard [2], p. 22). Among the most typical cognitive characteristics are "retention of large quantities of information, advanced comprehension, varied interests and high curiosity, and a high level of language development and verbal ability" (Clark, 2002 as cited in Reis \& Sullivan [3], p. 10). In a study of adolescent students academically gifted and creatively talented in math, Hong and Aqui [4] reported that gifted students use cognitive strategies more often than their not gifted counterparts. According to Shore and Kanevsky [5] there are seven aspects in which gifted children differ from others: 1) memory and the usage of prior knowledge (i.e., gifted children create fast links between newly acquired and existing knowledge, and know how to use both); 2) description of self-regulating processes (i.e., children with talent are more aware of their metacognitive processes); 3) speed of the thinking process (i.e., gifted students spend more time to retrieve the information needed to solve a problem, that is, more time on planning and less on reporting the solution); 4) internal representation and categorization (i.e., gifted children better exclude irrelevant data, go beyond the given information when representing the problem and use fewer category levels with more common elements between the problems); 5) the use of procedural knowledge, also known as the "how to" of solving problems (i.e., gifted children switch between different strategies easier and faster, e.g., in their trials they know why they attempt this, what to expect and what will follow next); 6) flexibility (i.e., the ability to see alternative ways to solve a problem or to represent it, especially when a 
change is needed for successful resolution of a task); 7) a preference for complexity in tasks, environments and learning. In Chile, Arancibia [6] indicates that students with academic talent tend to be more critical, insightful and curious, and possess a distinguished sense of humor.

\section{Academic Talent in the Context of Low Socioeconomic Status (SES)}

The "chronic underrepresentation" of low SES children in programs for gifted students is still among the most persistent problems in the area of gifted education (Borland [7]; McBee [8]). One of the biggest challenges these talented students face is their role as first-generation college students. As such, they have to cope with a series of difficulties-weaker study persistence habits, fewer connections with other college students, perceptions of weak family support, problems with time management, the complexity of the vocabulary used at the college level and the processing of written tasks (Gibbons, Pelchar, \& Cochran [9]).

Talented children who live in a vulnerable socioeconomical context are strongly affected by the lack of social policy that provides adequate opportunities and instruments to meet their specific educational needs (Arancibia [6]). The role of the socioeconomical context is studied in terms of heritability of intelligence from Turkheimer, Haley, Waldron, D'Onofrio and Gottesman [10]. The authors concluded that in families with low socioeconomic status, $60 \%$ of the variance in IQ is accounted by the shared environment (that is, the environment shared between the members of the family) and almost zero by the genes. As socioeconomic status increases, the role of the shared environment decreases and the contribution of genes increases (for more detailed analysis on hereditability, socioeconomic status and intelligence, see Nisbett et al. [11]). Nisbett et al. interpret some of the results from this study as "room for interventions" (Nisbett et al. [11], p. 134). More precisely, "One interpretation of the finding that heritability of IQ is very low for lower SES individuals is that children in poverty do not get to develop their full genetic potential. If true, there is room for interventions with that group to have large effects on IQ" (Nisbett et al. [11], p. 134).

The need for adequate environment and personal catalysts, as well as an informal-formal learning and practice process for the development of talent, is well supported by the Differentiated Model of Gifted and Talent (DMGT; Gagné, [12], [13]). In this way, low SES gifted students without adequate educational opportunities may not reach talent status, which implies the loss of prominent potential human capital as a consequence.

In Chile and generally in Latin America, no studies exist about the cognitive characteristics of gifted children who come from low socioeconomic status, which hinders the development of adequate policy in support of talent education. Especially in the cultural and economic context of countries in Latin America, a better understanding of this phenomenon is needed. Thus, the main goal of the present study is to explore the cognitive characteristics of gifted students in the specific context of low SES in Latin America.

\section{Method}

\section{Participants}

The participants in the present study were 5160 students who took part in the process of identification of gifted students from the program PENTA UC between 2001 and 2010, when the participants were in the fifth grade ${ }^{1}$. PENTA $\mathrm{UC}$ is an out-of-school program for children with academic talent. One distinctive characteristic of the program is that it functions during the whole school year, in which students attend the Pontific Catholic University of Chile every Friday and Saturday to study three courses per semester, specially designed for them, depending on their preferences. Their participation in the program can last up to seven years. PENTA UC is focused on students from public schools of the capital Santiago, representing the most economically vulnerable context in the capital. In 2012, for example, students from municipal schools ${ }^{2}$ represented $73 \%$ of the children nominated for the program during the identification process.

The identification process developed in PENTA UC consists of several stages and lasts approximately five months ${ }^{3}$. Every year, specially trained teachers or parents nominate approximately one thousand students. The process of nomination is based on a list of qualitative characteristics (for example, "student asks complex questions during classes"). After the initial nomination, students are evaluated with a test for cognitive abilities (Raven Progressive Matrices - General scale, Raven, Court, \& Raven [14]) and as a result, approximately two hundred and fifty students are selected for the program. The cutoff-point for selection is the $75^{\text {th }}$ percentile, calculated separately for each grade. Selected students represent between $1 \%$ and $1.5 \%$ of the population at this grade level (PENTA UC [15], [16]). At present, 860 students, aged between 11 and 18 years, attend the program.

The present study used data from the selection processes conducted between 2001 and 2010. Of the students, 55.4\% were boys and $44.6 \%$ were girls. It should be clearly noted that the two groups compared in this study are: gifted or selected students $(27.8 \%$ of the total sample of nominated students) and not gifted or selected students $(72.2 \%$ of the total sample of nominated students). Thus, the not gifted students are those who were nominated but not selected according to the cutoff-point of their results in the test for analytical abilities.

1 Data for the test results was not available for all students, which caused differences in the samples further in the analyses.

2 In Chile, municipal schools are completely economically supported by the state, and, generally, do not show particularly high results in national standardized tests. There are also partially subsidized schools (supported economically by the state and by the families of students) and private schools, which usually demonstrate the highest results in standardized national tests.

3Detailed information about the identification and selection process can be found in PENTA UC [15] and [16]. 


\section{Measures}

Cognitive abilities. According to Raven's personal notes, "He wanted to develop a series of overlapping, homogeneous problems whose solutions required different abilities" (Carpenter, Just and Shell [17], p. 408).Nowadays, Raven's Progressive Matrices Test - General scale (RPM) (Raven, Court \& Raven [14]) ${ }^{4}$ is a well-established non-verbal instrument for measurement of general intelligence consisting of five sets of problems. The problems from the first set, Set A, are "continuous patterns" (van der Ven and Ellis [18]), in which one part of the pattern is missing and the individual must choose the correct one from a list of suggestions. The cognitive ability involved here is a perceptual one. The other sets $(\mathrm{B}, \mathrm{C}, \mathrm{D}$ and $\mathrm{E})$ consist of twelve matrices of geometric figures. Each matrix consists of a sequence of four (for Set B) and nine (for Sets C, $\mathrm{D}$ and $\mathrm{E}$ ) figures, where one figure is missing from the sequence. The individual's task is to choose the correct missing figure from a set of options. Carpenter et al. [17] say that the RPM test is a measure of analytic intelligence, defined as "the ability to reason and solve problems involving new information, without relying extensively on an explicit base of declarative knowledge derived from either schooling or previous experience" (p. 404). To solve the RPM problems, individuals need to induce the theme of relations that connect designs between them and the rules that determine transitions into elements of rows and columns (Van der Ven \& Ellis [18]; Lynn, Allik, Pullmann, and Laidra [20]). As the difficulty of the problems in the test increases gradually, the student must apply a greater number of or more difficult rules, and more figural elements must be included per entry (Carpenter et al. [17]).

Although there is a general consensus that RPM is a $\mathrm{g}$ factor measure, some more recent studies (for example, Lynn et al. [20]; DeShon, Chan, \& Weissbein, [21]) show that RPM items can be grouped into different factors, each of which would indicate that the instruments can measure specific cognitive abilities as well. One of the earliest attempts to conceptualize the multidimensionality of Raven' progressive matrices comes from Hunt, who differentiates between two algorithms used to solve the problems in Advanced RPM: visual strategy (applying visual perception operations) and analytical strategy (related to the logical operation application) (Hunt, 1974 cited by DeShon et al. [21]).

Probably the most extensive description of the rules taxonomy is that proposed by Carpenter et al. [17], who also based their analysis on Raven's Advanced matrices:

1. "Constant in a row: The same value occurs throughout a row, but changes down a column.

2. "Quantitative pairwise progression: A quantitative increment or decrement occurs between adjacent entries in an attribute such as size, position, or number.

3. "Figure addition or subtraction: A figure from one

4 Norms for Chilean population aged from 5 to 22 years are available from Ivanovic et al. [19]. column is added to (juxtaposed or super imposed) or subtracted from another figure to produce the third.

4. "Distribution of three values: Three values from a categorical attribute (such as figure type) are distributed through a row.

5. "Distribution of two: Two values from a categorical attribute are distributed through a row; the third value is null" (Carpenter et al., [17], p.408).

Using Rasch analysis, Van der Ven \& Ellis [18] tested the unidimensionality of Raven's Standard matrices. Their results revealed that the model was not rejected for A, C and $\mathrm{D}$ sets, but in sets $\mathrm{B}$ and $\mathrm{E}$ analysis suggested at least two different dimensions. Further analysis revealed two principal factors in RPM. The first consists of items in which the solution is related with some Gestalt continuation rule: "The solution is found by just looking at the problem and waiting until one suddenly becomes aware of the complete Gestalt: the solution process is in itself almost unconscious" (p. 56). The factor include items of Set A and the first items of Set B.All other items are included in "Analogical Reasoning" factor (Van der Ven \& Ellis [18]). Here, individuals need to induce the rules to solve problems in a conscious way. The authors showed that in Set C, most of the items, except C7 and $\mathrm{C} 12$, are sensitive to a lack of resistance to perceptual distraction. Meanwhile, in Set E, some items need a specific kind of coping strategy to find the correct solution. These strategies are heterogeneous and characteristic of only one or two items.

Lynn et al. [20] found a three factor solution for RPM. The first factor is almost identical to the "Gestalt continuation" factor of Van der Ver \& Ellis [18], where the item's solution is obtained by perception of the pattern as a gestalt and identifying the appropriate piece for its completion without the use of complex reasoning. The second factor is called Verbal-Analytic Reasoning (Lynn et al. [20]). This solution is obtained through arithmetic addition and subtraction problems that require verbal reasoning. The authors indicate that this factor evaluates the ability to start with stated rules, premises or conditions and engage in one or more steps to reach a solution to a problem. The third factor, Visuospatial Ability (Lynn et al. [20]), evaluates the ability to rapidly perceive and manipulate visual patterns or to maintain orientation with respect to objects in space. Mackintosh \& Bennett [22] believe that Carpenter et al.'s taxonomy could represent the best context to understand the distinction between the two analytical factors identified by Lynn et al. [20] and earlier by DeShon et al. [21]. They suggested that rules 1,2 and 4 (Constant in a row, Pairwise progression and Distribution of three) could be applied to solve items from Sets B, C and D, and although not perfectly, rules 3 and 5 (addition or subtraction and distribution of two) could be applied for Set E and the last items of Sets C and D. In a study on gender differences in RPM, Mackintosh \& Bennett [22] "build" an instrument based on Raven standard and advanced matrices that contain the same number of items as Carpenter et al.'s rules. Their study indicated that although they are accepted as a measure of general intelligence, 
Raven's progressive matrices indicate that there are items which give advantage to male students - namely items from Set $\mathrm{E}$ that require the addition/subtraction and distribution of two rules, according to the taxonomy of Carpenter et al. [17].

Demographic information about gender and socioeconomic status (SES) was also available. In relation to SES, in Chile, the National Board of Student Support and Scholarships (Junta Nacional de Auxilio Escolar y Becas de Chile, JUNAEB) defined the concept of socioeconomic "vulnerability" (called "indice de vulnerabilidad", IVE) as a dynamic condition which results from the interaction between multiple risk and protection factors and which manifests itself in minor or major acts of social, economic, psychological, cultural, environmental or biological risks producing a comparative disadvantage between subject, families and communities. At the beginning of the study it was thought that the type of school - municipal, partially subsidized or private - could be used as markers for SES. But since there are schools in Santiago that are municipal but still do not represent low SES, it was decided that IVE could be used as an official and more accurate indicator of SES. In our sample, $68 \%$ of the students nominated between 2001 and 2010 come from schools with more than $60 \%$ vulnerability, and only $3 \%$ came from schools with less than $19 \%$ vulnerability.

\section{Procedure}

All data from the selection process of the Program since 2001 were merged together. Special attention was given to the unification of the variables and their characteristics, as the codification of the information through the years was not always the same. After the data were merged, additional information was searched from the Ministry of Education in order to classify the students' schools according to a unified measure of socioeconomic status (SES). The scores for cognitive abilities were first standardized by year and then added in a total score, which again was transformed in z-scores.

\section{Results}

\section{Cognitive Characteristics of Chilean Gifted and Not Gifted Students}

Analyses showed that a school's index of vulnerability (IVE) is a negatively correlated to students' cognitive abilities as measured by Raven's test $\left(r_{s}=-.194, p<.001\right)$. Although the magnitude of the relation is small, our results correspond with the theoretical expectations that the high economical vulnerability of students' context is related to a low performance in the cognitive ability test, and this is the area where it is most important to take educational interventions.
In order to determine the cognitive characteristics of the students, they were analyzed by Sets of items, and data from previous studies were applied as guidelines in the interpretation of the results. In the following paragraph, the variation of difficulty of the items of Raven's sets is presented by means of the error rates in percentages by sets for the Not Gifted Group ( $\mathrm{N}=3641)$ and the Gifted Group $(\mathrm{N}=1500)$ (Table 1). The percentage of errors is generally low for Set A and Set B of the Raven's problems for both the Gifted and Not Gifted Groups. The percentage of errors for Set $C$ is around the average percentage for the total test items, and it gradually rises for the last (most difficult) sets of problems: Set D and Set E. This suggests that there is a ceiling effect in the Raven scores for both groups, especially for Sets A and B, as well as for the first items of Sets C and D, which can be observed in Figures 1 to 5 .

Table 1. Rate of Errors in Percentages in Different Sets of Problems for Not Gifted and Gifted Groups.

\begin{tabular}{|c|c|c|c|c|c|c|}
\hline & Set A & Set B & Set C & Set D & Set E & Total \\
\hline $\begin{array}{c}\text { Not } \\
\text { Gifted }\end{array}$ & $9,1 \%$ & $16,9 \%$ & $32,3 \%$ & $26,3 \%$ & $71,5 \%$ & $31,2 \%$ \\
\hline Gifted & $2,6 \%$ & $3,8 \%$ & $14,6 \%$ & $12,9 \%$ & $38,6 \%$ & $14,5 \%$ \\
\hline
\end{tabular}

\section{Set A}

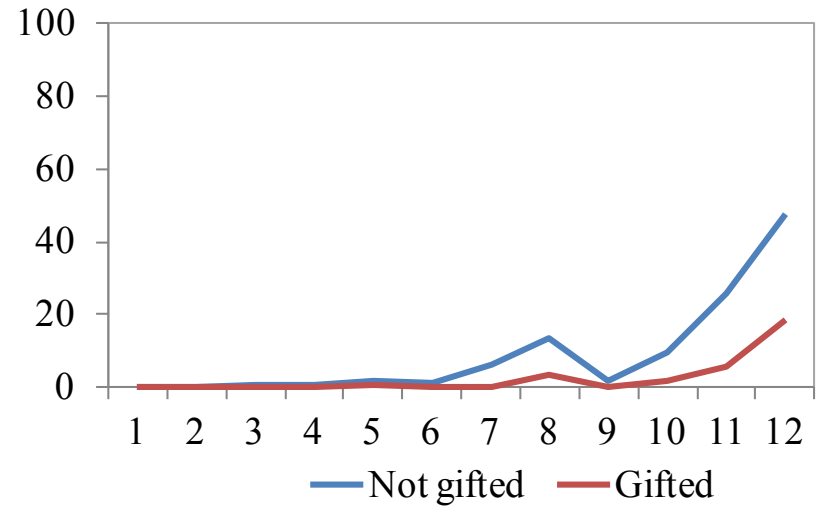

Figure 1. Percentage of errors in Set A for the twelve items

\section{Set B}

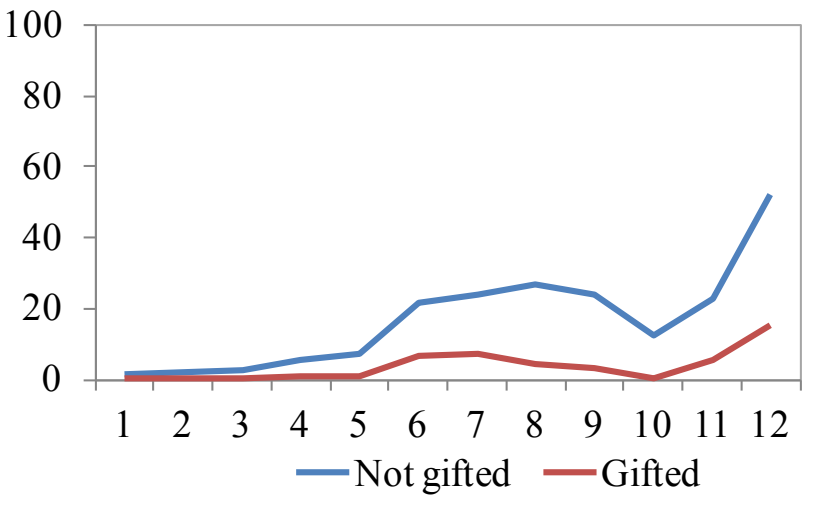

Figure 2. Percentage of errors in Set B for the twelve items 


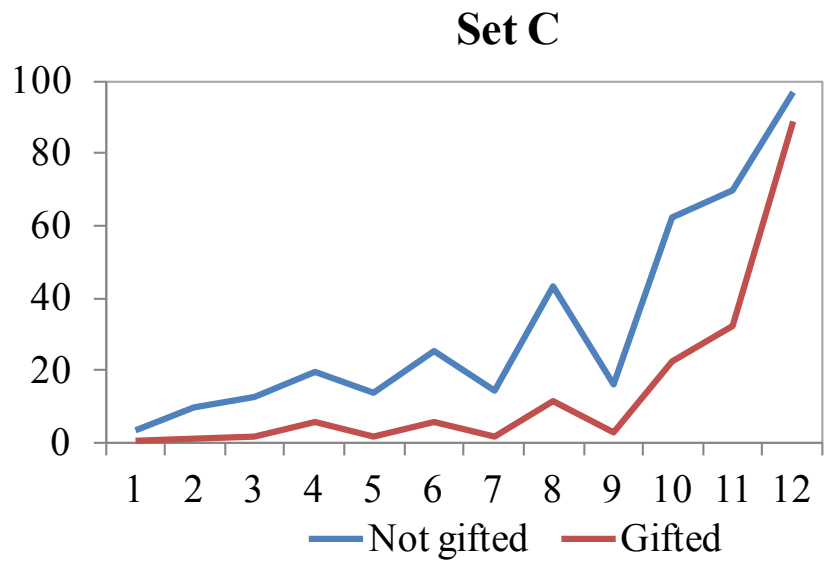

Figure 3. Percentage of errors in Set $\mathrm{C}$ for the twelve items

\section{Set D}

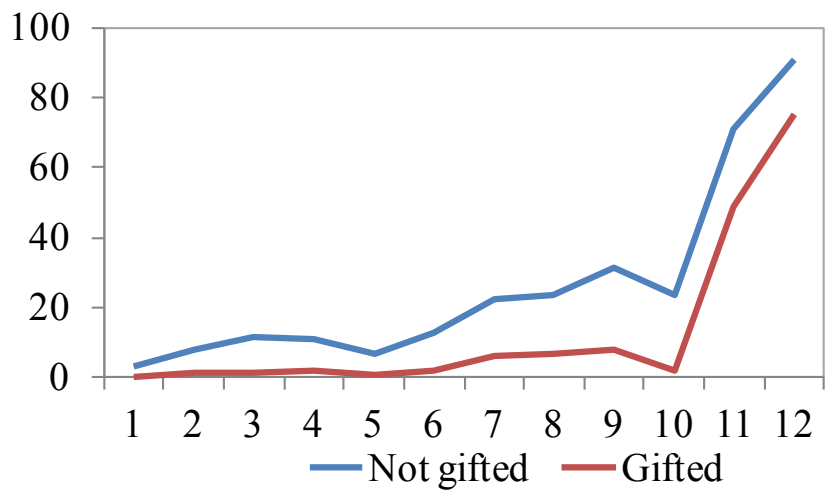

Figure 4. Percentage of errors in Set $\mathrm{D}$ for the twelve items

\section{Set E}

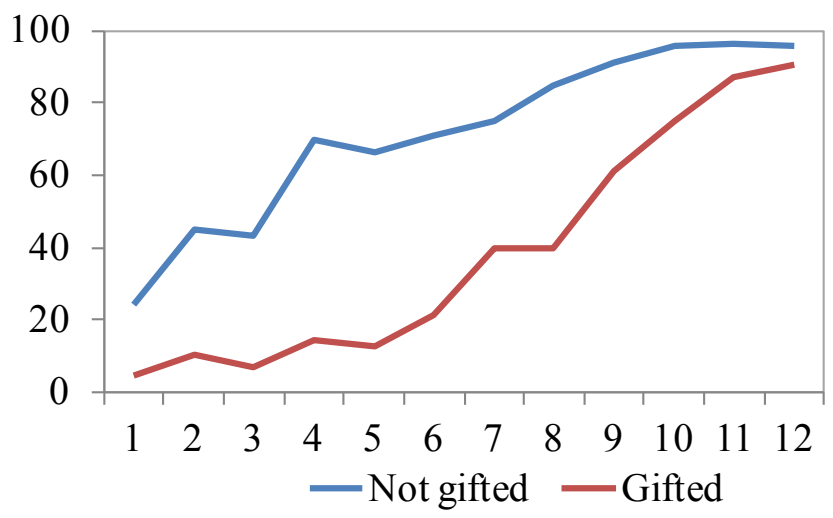

Figure 5. Percentage of errors in Set $\mathrm{E}$ for the twelve items
Analysis of variance was performed to explore the differences in cognitive abilities among four groups: gifted girls, gifted boys, not gifted girls and not gifted boys. Gender was considered in this analysis because in many studies gender differences are reported as an important aspect of cognitive abilities. Mackintosh and Bennett [22] demonstrated that gender differences exist in those groups of items that require the particular rules earlier described in Carpenter et al. [17]. For example, items in Set E that require "addition/subtraction" and "distribution of two" rules give a large male advantage (Mackintosh \& Bennett [22]). Savage-McGlynn [23] reported that there were no gender differences in intelligence in a nationally representative sample of 7- to 18-year-old students from the UK. Lynn (Irwing \& Lynn [24]; Lynn [25]) proposed a developmental theory according to which differences in progressive matrices between girls and boys could result from their different maturation rates. At the early ages of 12-15 years, girls outperform boys on abstract reasoning ability, but later, between 16 and 18 years of age, boys have an advantage in non-verbal ability (Lynn et al. [20]). Because of the developmental gender differences, Lynn et al. argue that in order to obtain consistent results, data from Raven progressive matrices should be analyzed considering age (Lynn et al. [20]). Our data meet this idea, as the students who participated in the present study were all in the fifth grade, aged 10-11 years. Students were divided into four groups and analyses were run separately for all of the Sets of Raven's SPM. Welch's F is reported because variances were not homogeneous. Results showed that there was a statistically significant difference between groups in all five sets of SPM (post-hoc comparisons are presented in Table 2). 
Table 2. Post-hoc Games-Howell comparisons between gifted boys, gifted girls, not gifted boys and not gifted girls in Sets A to E of Raven SPM.

\begin{tabular}{|c|c|c|c|c|c|c|c|}
\hline \multirow{2}{*}{$\begin{array}{c}\text { Dependent } \\
\text { Variable }\end{array}$} & \multirow{2}{*}{ (I) Gen_talent_grps } & \multirow{2}{*}{ Gen_talent_grps } & \multirow{2}{*}{$\begin{array}{c}\text { Mean Difference } \\
(\mathrm{I}-\mathrm{J})\end{array}$} & \multirow{2}{*}{ Std. Error } & \multirow{2}{*}{ Sig. } & \multicolumn{2}{|c|}{$95 \% \mathrm{CI}$} \\
\hline & & & & & & LowerBound & UpperBound \\
\hline \multirow{12}{*}{ Set A } & \multirow{3}{*}{ Notgifted boys } & Notgifted girls &, 043 &, 035 & ,612 &,- 048 &, 134 \\
\hline & & Gifted girls &,$- 746^{*}$ &, 031 &, 000 &,- 827 &,- 666 \\
\hline & & giftedboys &,$- 722 *$ &, 030 &, 000 &,- 798 &,- 646 \\
\hline & \multirow{3}{*}{ Notgifted girls } & Notgifted boys &,- 043 &, 035 & ,612 &,- 134 &, 048 \\
\hline & & Gifted girls &,$- 790^{*}$ &, 033 &, 000 &,- 875 &,- 705 \\
\hline & & Gifted boys &,$- 765^{*}$ &, 032 &, 000 &,- 846 &,- 684 \\
\hline & \multirow{3}{*}{ Gifted girls } & Notgifted boys &, $746^{*}$ &, 031 &, 000 & ,666 &, 827 \\
\hline & & Notgifted girls &, $790^{*}$ &, 033 &, 000 & ,705 &, 875 \\
\hline & & Gifted boys &, 024 &, 027 & ,799 &,- 045 &, 093 \\
\hline & \multirow{3}{*}{ Gifted boys } & Notgifted boys &, $722 *$ &, 030 &, 000 & ,646 & ,798 \\
\hline & & Notgifted girls &, $765^{*}$ &, 032 &, 000 & ,684 &, 846 \\
\hline & & Gifted girls &,- 024 &, 027 & ,799 &,- 093 &, 045 \\
\hline \multirow{12}{*}{ Set B } & \multirow{3}{*}{ Notgifted boys } & Notgifted girls &,- 039 &, 036 & ,692 &,- 131 &, 053 \\
\hline & & Gifted girls &,$- 849^{*}$ &, 028 &, 000 &,- 922 &,- 776 \\
\hline & & giftedboys &,$- 863^{*}$ &, 027 &, 000 &,- 931 &,- 794 \\
\hline & \multirow{3}{*}{ Notgifted girls } & Notgifted boys &, 039 &, 036 & ,692 &,- 053 &, 131 \\
\hline & & Gifted girls &,$- 810^{*}$ &, 031 &, 000 &,- 889 &,- 731 \\
\hline & & Gifted boys &,$- 824^{*}$ &, 029 &, 000 &,- 898 &,- 749 \\
\hline & \multirow{3}{*}{ Gifted girls } & Notgifted boys &, $849^{*}$ &, 028 &, 000 & ,776 & ,922 \\
\hline & & Notgifted girls &, $810^{*}$ &, 031 &, 000 &, 731 & ,889 \\
\hline & & Gifted boys &,- 014 &, 020 & ,896 &,- 064 &, 037 \\
\hline & \multirow{3}{*}{ Gifted boys } & Notgifted boys &, $863^{*}$ &, 027 &, 000 & ,794 &, 931 \\
\hline & & Notgifted girls &, $824^{*}$ &, 029 &, 000 &, 749 &, 898 \\
\hline & & Gifted girls &, 014 &, 020 &, 896 &,- 037 &, 064 \\
\hline \multirow{12}{*}{ Set C } & \multirow{3}{*}{ Notgifted boys } & Notgifted girls &, $131^{*}$ &, 033 &, 000 &, 047 & ,216 \\
\hline & & Gifted girls &,$- 982^{*}$ & 029 &, 000 & $-1,057$ &,- 907 \\
\hline & & Gifted boys & $-1,038^{*}$ &, 027 &, 000 & $-1,107$ &,- 968 \\
\hline & \multirow{3}{*}{ Notgifted girls } & Notgifted boys & $-1,038^{*}$ &, 033 &, 000 &,- 216 &,- 047 \\
\hline & & Gifted girls & $-1,113^{*}$ &, 032 &, 000 & $-1,194$ & $-1,032$ \\
\hline & & Gifted boys & $-1,169^{*}$ &, 030 &, 000 & $-1,245$ & $-1,093$ \\
\hline & \multirow{3}{*}{ Gifted girls } & Notgifted boys &, $982^{*}$ &, 029 &, 000 & ,907 & 1,057 \\
\hline & & Notgifted girls & $1,113^{*}$ &, 032 &, 000 & 1,032 & 1,194 \\
\hline & & Gifted boys &,- 056 &, 026 &, 130 &,- 121 &, 010 \\
\hline & \multirow{3}{*}{ Gifted boys } & Notgifted boys & $1,038^{*}$ &, 027 &, 000 & ,968 & 1,107 \\
\hline & & Notgifted girls & $1,169^{*}$ &, 030 &, 000 & 1,093 & 1,245 \\
\hline & & Gifted girls &, 056 &, 026 &, 130 &,- 010 &, 121 \\
\hline
\end{tabular}

* The mean difference is significant at the 0.05 level. 
Table 2 (continued). Post-hoc comparisons between talented boys, talented girls, not talented boys and not talented girls in Sets A to E of Raven SPM.

\begin{tabular}{|c|c|c|c|c|c|c|c|}
\hline \multirow{2}{*}{$\begin{array}{l}\text { Dependent } \\
\text { Variable }\end{array}$} & \multirow{2}{*}{ (I) Gen_talent_grps } & \multirow{2}{*}{$\frac{(\mathrm{J})}{\text { Gen_talent_grps }}$} & \multirow{2}{*}{ Mean Difference (I-J) } & \multirow{2}{*}{ Std. Error } & \multirow{2}{*}{ Sig. } & \multicolumn{2}{|c|}{$95 \% \mathrm{CI}$} \\
\hline & & & & & & LowerBound & UpperBound \\
\hline \multirow{12}{*}{ Set D } & \multirow{3}{*}{ Notgifted boys } & Notgifted girls &,$- 187^{*}$ &, 035 &, 000 &,- 277 &,- 098 \\
\hline & & Gifted girls &,$- 969^{*}$ &, 031 &, 000 & $-1,050$ &,- 889 \\
\hline & & Gifted boys &,$- 885^{*}$ & ,029 &, 000 &,- 959 &,- 810 \\
\hline & \multirow{3}{*}{ Notgifted girls } & Notgifted boys &, $187^{*}$ &, 035 &, 000 & ,098 &, 277 \\
\hline & & Gifted girls &,$- 782^{*}$ &, 032 &, 000 &,- 865 &,- 699 \\
\hline & & Gifted boys &,$- 697^{*}$ & 030 &, 000 &,- 774 &,- 620 \\
\hline & \multirow{3}{*}{ Gifted girls } & Notgifted boys &, $969^{*}$ & 031 &, 000 &, 889 & 1,050 \\
\hline & & Notgifted girls &, $782^{*}$ &, 032 &, 000 & ,699 &, 865 \\
\hline & & Gifted boys &, $085^{*}$ &, 026 &, 006 &, 018 &, 152 \\
\hline & \multirow{3}{*}{ Gifted boys } & Notgifted boys &, $885^{*}$ & ,029 &, 000 &, 810 & ,959 \\
\hline & & Notgifted girls & $697^{*}$ &, 030 &, 000 & 620 &, 774 \\
\hline & & Gifted girls &,$- 085^{*}$ &, 026 &, 006 &,- 152 &,- 018 \\
\hline \multirow{12}{*}{ Set E } & \multirow{3}{*}{ Notgifted boys } & Notgifted girls &, $120^{*}$ &, 025 &, 000 & 057 &, 183 \\
\hline & & Gifted girls & $-1,414^{*}$ &, 031 &, 000 & $-1,493$ & $-1,335$ \\
\hline & & Gifted boys & $-1,523^{*}$ &, 028 &, 000 & $-1,595$ & $-1,452$ \\
\hline & \multirow{3}{*}{ Notgifted girls } & Notgifted boys &,$- 120^{*}$ &, 025 &, 000 &,- 183 &,- 057 \\
\hline & & Gifted girls & $-1,534^{*}$ &, 031 &, 000 & $-1,614$ & $-1,454$ \\
\hline & & Gifted boys & $-1,643^{*}$ &, 028 &, 000 & $-1,716$ & $-1,571$ \\
\hline & \multirow{3}{*}{ Gifted girls } & Notgifted boys & $1,414^{*}$ &, 031 &, 000 & 1,335 & 1,493 \\
\hline & & Notgifted girls & $1,534^{*}$ &, 031 &, 000 & 1,454 & 1,614 \\
\hline & & Gifted boys &,$- 109^{*}$ &, 034 &, 006 &,- 196 &,- 023 \\
\hline & \multirow{3}{*}{ Gifted boys } & Notgifted boys & $1,523^{*}$ &, 028 &, 000 & 1,452 & 1,595 \\
\hline & & Notgifted girls & $1,643^{*}$ &, 028 &, 000 & 1,571 & 1,716 \\
\hline & & Gifted girls & $109^{*}$ &, 034 &, 006 & 023 & , 196 \\
\hline
\end{tabular}

* The mean difference is significant at the 0.05 level.

It can be observed from Figure 6 that in the easiest set of problems, Set A, gifted girls had the highest mean score, which differed significantly from both not gifted boys and not gifted girls(Welch $\mathrm{F}[3,2436]=387.41, \mathrm{p} \leq .001, \eta^{2}=$ $0,12)^{5}$. Gifted boys also differed significantly from all not gifted children. Gender differences between children in the same "talent" group were not significant (Figure 6). This suggests that the differences in these items are due to gifted children's better ability to use the Gestalt Continuation rule (as described by both Van der Ven \& Ellis [18] and supported by Lynn et al. [20]), that is, the "perception of the pattern as a gestalt and the identification of the appropriate piece for its completion without the use of reasoning as a solution" (Lynn et al. [20], p. 417).

5 Eta squared is calculated as suggested by Field, A. [26]

\section{Set A}

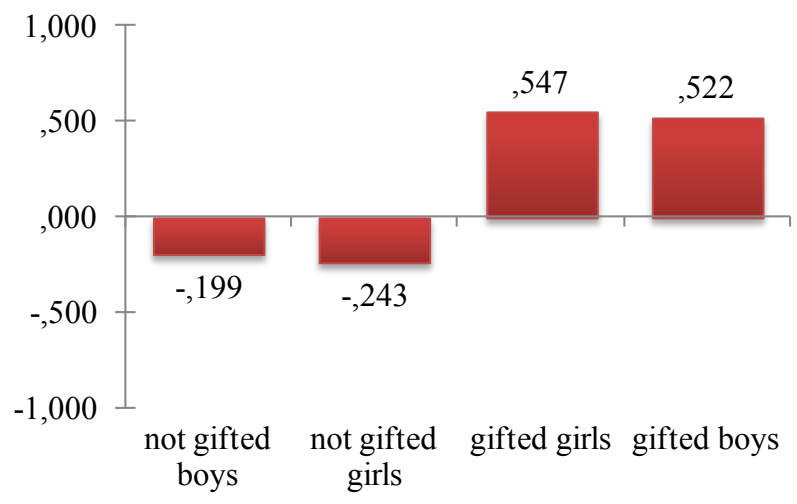

Figure 6. Mean scores in Set A of not gifted boys, not gifted girls, gifted boys and gifted girls. 
In Set $\mathbf{B}$ (Figure 7), gifted boys demonstrated the highest scores among all students, but similarly to Set A, their mean score was significantly higher than only not gifted students $\left(\right.$ Welch F [3, 2515] $\left.=581.91, p \leq .001, \eta^{2}=0,15\right)$. As in Set A, boys and girls did not differ significantly in either the gifted or the not gifted group. It is more difficult to understand the differences in this set because previous researchers interpreted it in different ways. While Van der Ven \& Ellis [18], using Rasch analysis, identified items B3 to B7 as similar to Set A items where the Gestalt Continuation rule is applicable, they identified later items B8 to B11 as needing analogical reasoning. Meanwhile, Lynn et al. [20] also describe B1 to B4 as Gestalt Continuation, but they describe items B5 to B12 as needing Visuospatial ability (the ability to perceive and manipulate visual patterns).

\section{Set B}

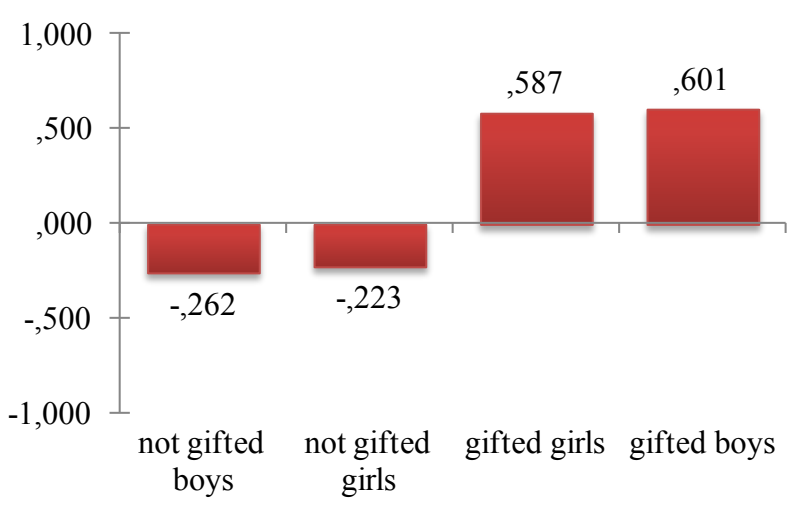

Figure 7. Mean scores in Set B of not gifted boys, not gifted girls, gifted girls and giftedboys.

According to Mackintosh \& Bennet [22], the first three rules form Carpenter et al.'s taxonomy- "Constant in a row" (the same value of an attribute appears in all three figures in a row, but changes between rows), "Distribution of three values" (three different values of an attribute appears in each of the three figures of a row) and "Pairwise progression" (a constant increment or decrement occurs in the size, number or position on an attribute between adjacent figures) - are sufficient to solve the problems from Set B, as well as Sets C and $\mathrm{D}$.

In Set $\mathrm{C}$, in which most of the items involve analogical reasoning (Van der Ven \& Ellis [18]), gifted boys had the highest scores, which were significantly different from all not gifted students but not from gifted girls (Welch $F[3$, $2409]=910.21, p \leq .001, \eta^{2}=0,24$ ) (Figure 8). Additionally, for the first time in the analysis, some gender differences emerged, though only in the group of not gifted students. It seems that as the difficulty of the problems increased, boys and girls in the same "talent" group showed gendered differences in their reasoning abilities. There are different interpretations of the items from Set C. Van der Ven \& Ellis [18] identified that the majority of the items from this set contains not only analogical reasoning items but also some items where perceptual distraction takes part, which they defined as "lack of resistance to perceptual distracters" (p. 54). According to Lynn et al. [20], some of the earlier items of Set $\mathrm{C}$ are based on Gestalt continuation, and some of the later ones on verbal-analytic reasoning (defined as "arithmetical addition and subtraction problems that require verbal reasoning for their solution," p. 418) and visuospatial ability (in which the solution is result from perceptual processes). This result could be further interpreted in the context of Mackintosh \& Bennett [22], who reported that most of the items from Set $\mathrm{C}$ require the addition/subtraction (a figure from one column is added to or subtracted from another figure to produce the third) or distribution of two rules (two values of an attribute occur in each row, with the third value being null), and all items in Set $\mathrm{C}$ require the pairwise progression rule (a constant increment or decrement occurs in the size, number or position on an attribute between adjacent figures).

\section{Set C}

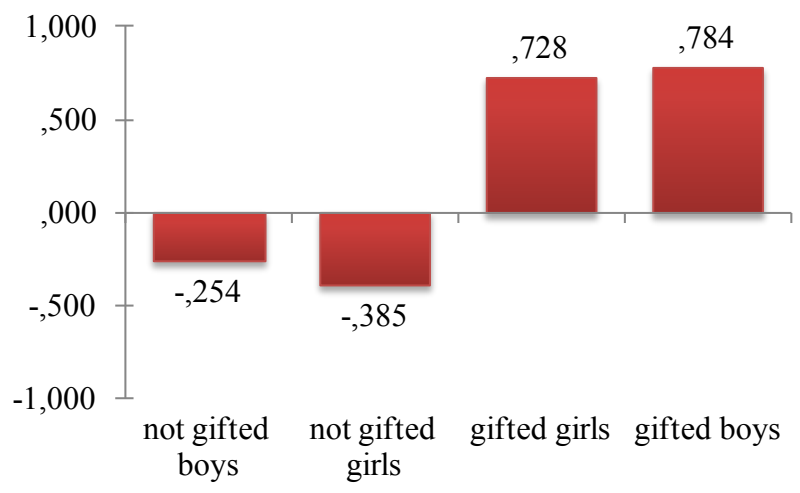

Figure 8. Mean scores in Set $\mathrm{C}$ of not gifted boys, not gifted girls, gifted girls and gifted boys.

As a summary of cognitive characteristics of gifted students so far, we can conclude that when solving Sets A, B and $\mathrm{C}$ of the Raven's problems, gifted children have a better perception of the pattern as a gestalt, a better ability to perceive and manipulate visual patterns and a higher capacity to apply the "Constant in a row," "Distribution of three values" and "Pairwise progression" rules.

\section{Set D}

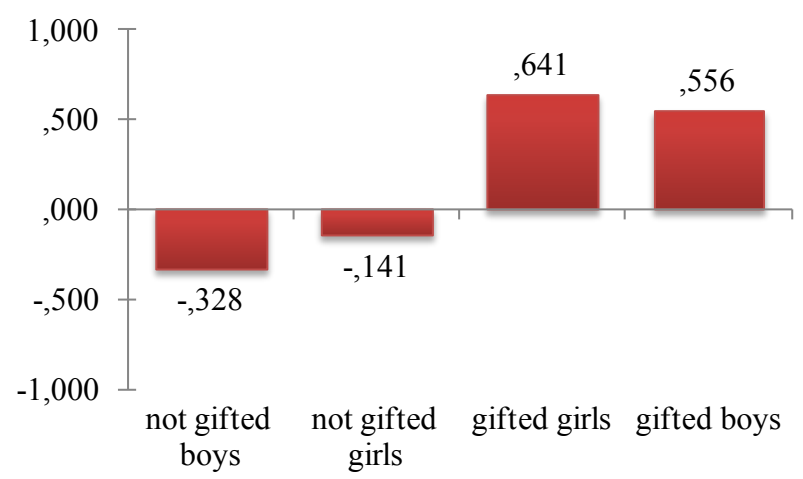

Figure 9. Mean scores in Set D of not gifted boys, not gifted girls, gifted girls and gifted boys. 
An even more specific profile of gifted boys and girls was revealed in the last two Sets, D and E, in which all the groups differed significantly from each other (Welch $\mathrm{F}[3,2421]=$ $508.78, \mathrm{p} \leq .001, \eta^{2}=0,15$ for Set $\mathrm{D}$ and Welch $\mathrm{F}[3,2084]=$ $1845.40, p \leq .001, \eta^{2}=0,49$ for Set E) (Figure 9 and Figure $10)$.

According Mackintosh and Bennett [22], all items of Set D require the application of the distribution of three rule ("a different value of an attribute appears in each of the three figures of a row", p 665). In this set, gifted girls demonstrated the highest results and their mean score was significantly higher than all three groups, including gifted boys, which had not been previously observed in the present study. The unidimensionality of Set D was reported in Van der Ven \& Ellis [18], who furthermore described items from this set as analogical reasoning. Lynn et al. $[20]^{6}$ named it visuospatial ability. In Set $\mathrm{D}$, gifted girls demonstrated the highest results, significantly, compared with all other groups, but more importantly, a gender difference among talented students is revealed in the present study. This suggests that gender differences in analytical reasoning do exist between gifted boys and girls.

\section{Set $\mathbf{E}$}

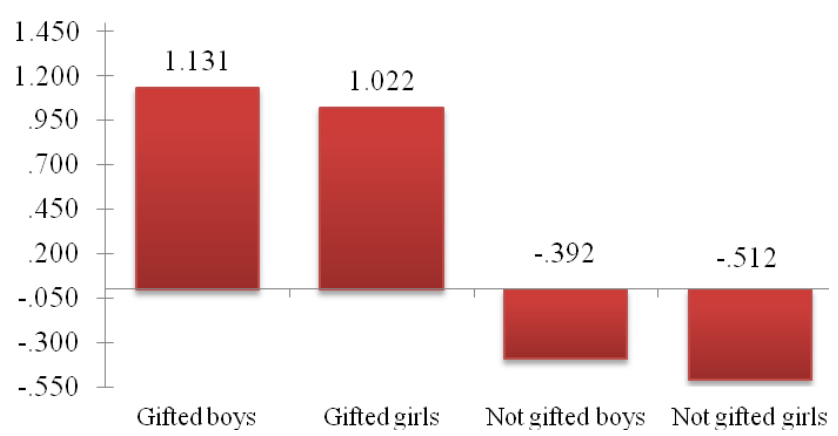

Figure 10. Mean scores in Set D of not gifted boys, not gifted girls, gifted girls and gifted boys.

Figure 10 presents the mean scores of the four groups in Set E. According to the post-hoc analyses, all four groups differed statistically significantly from each other, which suggested that not only talent but also gender play roles in the abilities to solve the type of problems that Set $\mathrm{E}$ contains.

In Set E, talented boys demonstrated the highest results, significantly, compared to the other three groups. This suggests that the cognitive abilities applied in this type of problems are more prevalent in gifted boys. According to Macintosh and Bennett [22], Set E contains addition/subtraction (a figure from one column is added to or subtracted from another figure to produce the third) and distribution of two (two values of an attribute occur in each row, with the third value being null) rules. According to Lynn et al. [20], the majority of items represent verbal-analytic reasoning, and according to Van der Ven \& Ellis [18], Set E is not unidimensional, and although it

6 The D12 item from this Set is described as Verbal-analytic Reasoning by Lynn et al. and as Addition or Subtraction / Distribution of two by Mackintosh and Bennett. requires analogical reasoning skills, there is also a second multidimensional, unidentified factor.

\section{Discussion and Practical Implications of the Results}

Our results showed that in all sets of Raven progressive matrices, gifted students have significantly higher scores than not gifted ones, suggesting that the former perform better in both perceptual and analytical cognitive abilities. This implies that gifted children better apply their abstract thinking ability and usage of complex rules to relate to and manipulate visual patterns. Gifted boys and girls can detect the presence of complex patterns of relation and rules between factors, and use it to solve problems correctly. Considering that the rate of error is highest in the most difficult set, Set E, we can conclude that one of the differences between not gifted and gifted students is that the latter can work well in terms of manipulating complex information. Following Van der Ven's \& Ellis' [18] idea of a "lack of resistance to perceptual distracters" factor in Set C, we can suppose that gifted children can maintain a reasoning approach to problems independently of the presence of perceptual characteristics than can affect the results. This can explain why in Set A, which requires "gestalt continuation" ability, gifted students also showed better performance - they probably address the problems in set A in an analytical way even if it is "unnecessary" to use reasoning abilities to solve them.

Gender differences emerged in Set $\mathrm{C}$ only for not gifted students. Since there are different interpretations of the items from Set C (some are identified as perceptual and others as analytical), we cannot clearly identify the specific cognitive abilities behind these items. In this direction, further analyses could be applied to reveal the factor structure of Raven's matrices in the population of academically gifted students. In Set $\mathrm{D}$ and Set $\mathrm{E}$, gender differences emerged in all groups.

While in the most difficult sets, Set D and Set E, gifted children again demonstrated significantly higher scores, the revealed gender differences among all the groups suggested some particular specifics in the cognitive abilities of the fifth graders. These results are especially important in the field of gifted education, as they suggest that gifted boys and girls differ in their reasoning and might need more detailed identification processes and educational services. Considering Set $\mathrm{D}$, there is a general agreement that this is a unidimensional factor (Van der Ven \& Ellis [18]), which involves analogical reasoning (Van der Ven \& Ellis [18]) and follows the rule that a different value of an attribute appears in each of the three figures of a row (Mackintosh and Bennett [22]). Gifted girls showed the highest score in this set, which suggests that they have a particular advantage over gifted boys in the use of visuospatial abilities to detect the presence of different presentations (in this case, three) of the same characteristic during problem resolution. Conversely, in Set E talented boys demonstrated the highest 
scores. The unidimensionality of this set is again under discussion, but Mackintosh and Bennett [22] describe the majority of the items therein as requiring the addition/subtraction and distribution of two rules. In general, our results may show that gifted boys use verbal analytic reasoning better than gifted girls to abstract arithmetical relations (of addition and subtraction) between attributes of problems. Furthermore, gifted boys can better detect and use the presence, absence and change of an attribute of the problems. Following Van der Ven \& Ellis [18], these results in Set $\mathrm{E}$ can be understood to show that gifted boys can make better use of verbal analytic reasoning to perform specific coping strategies to solve problems, which can be novel in relation to previous problems. According to Van der Ven \& Ellis [18] on the other hand, both Set D and Set E represent analogical reasoning items, which do not explain why in Set $\mathrm{D}$ in our sample talented girls hadthe highest scores butin Set E talented boys demonstrated highest results. Further research should be made on the factor structure of the test in the gifted population in order to contribute to the knowledge in this area.

As a summary, our results showed that gifted Chilean students possess specific cognitive characteristics and differ from not gifted ones in their perceptual and analytical abilities, even at the early age of 10-11 years, and in economically vulnerable context.

The presence of the ceiling effect among children who are nominated to participate in the program suggests that it might be more appropriate for Advanced Progressive Matrices to be applied when selecting talented students because of the low error rate, especially in the first items of the test. Gender differences should also be considered in this process.

Talent development requires the educational context of gifted students to detect and satisfy their special educational needs. Teachers should generate the conditions to practice specifically gifted abilities, creating activities and challenges that fit with their potential. Our results provide information on a set of cognitive characteristics, typical for Chilean gifted students, as well as on differences between gifted boys and girls. Teachers and specialists in the area can consider this information during both the identification and teaching processes. In this way, not only would a better educational service be provided but also "lost talent" among children with low socioeconomic status in Chile could be prevented.

\section{Acknowledgements}

This research was supported by Fondo Nacional de Desarrollo Científico y Tecnológico (FONDECYT) Proyecto Fondecyt Regular 2011, Numero 1110948.

\section{REFERENCES}

[1] Steiner, H.H., \& Carr, M. (2003). Cognitive Development in Gifted Children: Toward a More Precise Understanding of Emerging Differences in Intelligence. Educational Psychology Review, 15, 215-246.

[2] Robinson, A., \& Clinkenbeard, P.R. (2008). History of giftedness: Perspectives from the past presage modern scholarship. In S. I. Pfeiffer (Ed.), Handbook of giftedness in children: Psychoeducational theory, research, and best practices. (pp. 13-31). New York, NY US: Springer Science + Business Media.

[3] Reis, S.M., \& Sullivan, E.E. (2008). Characteristics of gifted learners: consistently varied; refreshingly diverse. Methods and materials for teaching the gifted, (pp. 3-36): Waco, TX: Prufrock Press.

[4] Hong, E., \& Aqui, Y. (2004). Cognitive and Motivational Characteristics of Adolescents Gifted in Mathematics: Comparisons Among Students With Different Types of Giftedness. Gifted Child Quarterly, 48(3), 191-201. doi: $10.1177 / 001698620404800304$.

[5] Shore, B.M., \& Kanevsky, L.S. (1993). Thinking processes: Being and becoming gifted. In K. A. Heller, F. J. Mönks \& A. H. Passow (Eds.), International handbook of research and development of giftedness and talent. (pp. 133-147). Elmsford, NY US: Pergamon Press.

[6] Arancibia, V. (2009) La educación de alumnos con talentos: una deuda y una oportunidad para Chile. Temas de la agenda pública año 4, Numero 26, Vicerrectoria de Comunicaciones y Asuntos Públicos, Pontificia Universidad Católica de Chile.

[7] Borland, J. H. (2008). Identification. In J. A. Plucker \& C. M. Callahan (Eds.), Critical issues and practices in gifted education: What the research says. (pp. 261-280). Waco, TX US: Prufrock Press.

[8] McBee, M.T. (2006). A Descriptive Analysis of Referral Sources for Gifted Identification Screening by Race and Socioeconomic Status. Prufrock Journal, 17(2), 103-111. doi: 10.4219/jsge-2006-686.

[9] Gibbons, M.M., Pelchar, T.K., \& Cochran, J.L. (2012). Gifted Students From Low-Education Backgrounds. Roeper Review, 34(2), 114-122.

[10] Turkheimer, E., Haley, A., Waldron, M., D'Onofrio, B., \& Gottesman, I.I. (2003). Socioeconomic Status Modifies Heritability of IQ in Young Children. Psychological Science, 14(6), 623-628. doi: 10.1046/j.0956-7976.2003.psci_1475.x.

[11] Nisbett, R.E., Aronson, J., Blair, C., Dickens, W., Flynn, J., Halpern, D.F., \& Turkheimer, E. (2012). Intelligence: New findings and theoretical developments. American Psychologist, 67(2), 130-159. doi: 10.1037/a0026699.

[12] Gagné, F. (2004). Transforming gifts into talents: the DMGT as a developmental theory. High Ability Studies, 15(2), 119-147. doi: 10.1080/1359813042000314682.

[13] Gagné, F. (2005). From gifts to talents: The DMGT as a developmental model. In R. J. Sternberg \& J. E. Davidson (Eds.), Conceptions of giftedness (2nd ed., pp. 98-120). Cambridge, UK: Cambridge University Press.

[14] Raven, J.C., Court, J.H.,\& Raven, J. (1996). Test de matrices progresivas. Escalas coloreada, general y avanzada. Buenos Aires: Paidós. 
[15] Programa Educacional para Niños con Talentos Académicos [PENTA-UC]. (2001a). Componente educacional. Sistema de selección e identificación de los alumnos. (Documento interno). Santiago, Chile.

[16] Programa Educacional para Niños con Talentos Académicos [PENTA-UC]. (2001b). Guía para la identificación de alumnos/as con talentos académicos destacados. (Documento interno). Santiago, Chile.

[17] Carpenter, P. A., Just, M.A., \& Shell, P. (1990). What one intelligence test measures: A theoretical account of the processing in the Raven progressive matrices test. Psychological Review, 97(3), 404-431.

[18] Van der Ven, A. H. G. S., \& Ellis, J. L. (2000). A Rasch analysis of Raven's standard progressive matrices. Personality and Individual Differences, 29, 1, 45-64. doi: 10.1016/s0191-8869(99)00177-4.

[19] Ivanovic, R., Forno, H., Durán, M., Hazbún, J., Castro, C., \& Ivanovic, D. (2000). Estudio de la capacidad intelectual (test de matrices progresivas de Raven) en escolares chilenos de 5 a 18 años: I. Antecedentes generales, normas y recomendaciones. Revista de psicología general y aplicada(53), 5-30.

[20] Lynn, R., Allik, J., Pullmann, H., \& Laidra, K. (2004) Sex differences on the progerssive matrices among adolescents. Some data from Estonia. Personality and Individual
Differences, 36, 1249-1255.

[21] DeShon, R. P., Chan, D., \& Weissbein, D. A. (1995). Verbal overshadowing effects on Raven's advanced progressive matrices: Evidence for multidimensional performance determinants. Intelligence, 21(2), 135-155. doi: 10.1016/016 0-2896(95)90023-3.

[22] Mackintosh, N.J., \& Bennett, E.S. (2005). What do Raven's Matrices measure? An analysis in terms of sex differences. Intelligence, 33(6), 663-674. doi: 10.1016/j.intell.2005.03.00 4.

[23] Savage-McGlynn, E. (2012). Sex differences in intelligence in younger and older participants of the Raven's Standard Progressive Matrices Plus. Personality and Individual Differences, 53(2), 137-141. doi: http://dx.doi.org/10.1016/j. paid.2011.06.013.

[24] Irwing, P., \& Lynn, R. (2005). Sex differences in means and variability on the progressive matrices in university students: A meta-analysis. [Article]. British Journal of Psychology, 96(4), 505-524. doi: 10.1348/000712605x53542.

[25] Lynn, R. (1999). Sex differences in intelligence and brain size: a developmental theory. Intelligence, 27(1), 1-12. doi: 10.1016/s0160-2896(99)00009-4.

[26] Field, A. (2009) Discovering statistics using SPSS, 3rd edition, SAGE Publications Ltd. 